\title{
The Concern of Nature Condition and Ecological Behavior's Practice Among Natural Science Students: Postgraduate Students of School of Environmental Science
}

\author{
Intan Nurul Aini ${ }^{1 *}$, Hayati Sari Hasibuan ${ }^{2}$ \\ ${ }^{1}$ School of Environmental Science, Universitas Indonesia, Special Capital Region of Jakarta, \\ Indonesia \\ ${ }^{2}$ School of Environmental Science, Universitas Indonesia, Special Capital Region of Jakarta, \\ Indonesia
}

\begin{abstract}
Natural science students are intended to have more sense of nature connectedness than non-natural science students because their understanding and awareness about environment they received from environmental education. Together, sense of nature connectedness, environmental understanding and awareness encourage those students to behave environmentally in the sake of nature protection. This study was undertake to confirm the positive correlation between those previous factors (the predictor) and the practice of pro-environmental behavior among natural science students (the response). Utilizing a semiquantitative online questionnaire and Gamma correlation analysis, this study identified that the concern of nature condition was positively correlate with PEB practice among natural science students. However, the correlation was strong only when respondents did PEB practice oftenly. The conclusion of this study is the environmental concern has positive contribution to PEB practice, but the occurance of PEB practice is more influenced by how often the PEB is performed by natural science students.
\end{abstract}

\section{Introduction}

School of Environmental Science was officially formed in 2016 and became the first school with multidisciplinary approach of environmental science in " $X$ " University in Jakarta. Actualizing the vision of this university to be "World Class Research University" with sustainability development-oriented is the main consideration of this school's establishment. During the process to achieve the vision, this school requires their students to master some learning outcomes, such as: comprehending and applying the basic concept and theory of environmental science; and analysing the environmental issues and solving it with the environmental science-approach.

\footnotetext{
* Corresponding author: intannurulaini06@gmail.com
} 
In order to achieve those outcomes, this school includes some courses relate to environmental science with the expectations of forming the understanding of environment essence (its phenomenas, facts, and potentials to sustain all living creatures' lives,) and environmental behavior (how to protect the environment in order of maintaining the environment quality) among students [1-2].

Learning environmental studies would affect natural sciences students to feel more engaged towards nature more than non-natural sciences students; and that sense of belonging would encourage them to behave environmentally, like no littering, undertake some recycling process, water consumption saving, taking eco-friendly transportation to go to places, and reducing any wooden chopstick use [3-5]. Based on the positive correlation between environmental education and environmentally behavior, this study was undertake to observe PEB practice among natural science students in daily life due to their concern of actual condition of nature. This study assumed that the concern of nature condition is the outcome of environmental science learning process by students of school of environmental science.

\section{Method Of Study}

\subsection{Data Collection}

This study was undertaken in January 2018 at "X" university in Jakarta, Indonesia. This study employed quantitative method with online questionnaire (Google Form) as the tool to collect data about environmental knowledge among students and some forms of PEB that students performed in their daily life. The questionnaire were distributed to 100 active postgraduate students who were in Semester 1-4 (alumnis and students who were above Semester 4 were excluded) in January 2018 through Whatsapp ${ }^{\circledR}$ as an online messaging application. There were 37 respondents who returned the questionnaire.

The questionnaire form were consist of items about environmental attitudes and forms of PEB. Some forms of PEB were sorted into 2 categories: technical/behavioural change and saving behaviour. There were also items about individual/respondents characteristics [6]. The form also consists of items about environmental knowledge and awareness based on respondents perspectives. This study modified the environmental attitudes to PEB practice predictor due to the purpose of this study.

Each item was sorted to different section: items of individual/respondents characteristics were sorted into Section A; items about environmental knowledge and awareness based on respondents perspectives were sorted into Section B; while items of PEB practice predictor and forms of PEB were sorted into Section C. This questionnaire also provided essay items about respondents perspectives about some forms of environmental issues caused by human activities. The data from this essay was the secondary data B to provide broader image of environmental science students understanding about environmental issues.

Items about PEB practice was assessed between 1-5 of Likert scale $(11=$ never, $2=$ rare, $3=$ sometimes, $4=$ often). Item about PEB practice predictor was also assessed by Likert scale $(1=$ strongly disagree, $2=$ disagree, $3=$ unsure/neutral, $4=$ agree, $5=$ strongly agree $)$. Section A was assessed by Guttman Scale ( $1=$ yes; $2=$ no) (Table 1$)$. 
Table 1. Questionnaire Items of Each Section

\begin{tabular}{|c|c|c|c|}
\hline Section & & Items & Scale \\
\hline \multirow{3}{*}{ A } & \multirow{3}{*}{$\begin{array}{l}\text { Respondents } \\
\text { characteristics }\end{array}$} & Age Groups & Nominal \\
\hline & & Semester & Nominal \\
\hline & & $\begin{array}{l}\text { Education Status (students of master programme } \\
\text { or doctoral programme) }\end{array}$ & Nominal \\
\hline \multirow{3}{*}{$\mathrm{B}$} & \multirow{3}{*}{$\begin{array}{l}\text { Environmental } \\
\text { Knowledge } \\
\text { and } \\
\text { Awareness }\end{array}$} & $\begin{array}{l}\text { Nature is the most important component of } \\
\text { environmental science. }\end{array}$ & Nominal \\
\hline & & Nature is in good condition & Nominal \\
\hline & & $\begin{array}{l}\text { The ability of environment to sustain humans } \\
\text { life due to its actual condition }\end{array}$ & Nominal \\
\hline \multirow{9}{*}{$\mathrm{C}$} & $\begin{array}{l}\text { PEB } \\
\text { Practice's } \\
\text { Predictor }(\mathrm{C} 1)\end{array}$ & $\begin{array}{l}\text { Respondents willingness to behave } \\
\text { environmentally due to their concern of nature } \\
\text { condition }\end{array}$ & Ordinal \\
\hline & \multirow{8}{*}{$\begin{array}{l}\text { Forms of Pro- } \\
\text { environmental } \\
\text { Behavior }(\mathrm{C} 2)\end{array}$} & Technical/behavioral change & \\
\hline & & $\begin{array}{l}\text { Separation of waste types (organic and } \\
\text { anorganic materials) (PEB 1) }\end{array}$ & Ordinal \\
\hline & & $\begin{array}{l}\text { Use of public transportation for long trips (PEB } \\
\text { 2) }\end{array}$ & Ordinal \\
\hline & & Use of recycle goods (PEB 3) & Ordinal \\
\hline & & Saving behaviour & \\
\hline & & $\begin{array}{l}\text { Turn off the electricity lines when not using it } \\
\text { (PEB 4) }\end{array}$ & Ordinal \\
\hline & & Turn off the water tap when not using it (PEB 5) & Ordinal \\
\hline & & Minimalisation of paper materials use (PEB 6) & Ordinal \\
\hline
\end{tabular}

The test of normality (Shapiro Wilk), validity (Pearson Correlation), and reliability (Cronbach's Alpha) of questionnaire $(r$ value $=0.3246$ ) were employed to all data of each section. The questionnaire were valid and reliable $(\alpha=0.05$; Cronbach's Alpha $0.677>$ $0.6)$, however data weren't distribute normally because the significant value was less than $\alpha$ $=0.05$. In terms of the condition, data were analysed with non-parametric statistic by Gamma correlation $(\alpha=0.05)$.

The correlation analysis was employed only for data in Section $\mathrm{C}$ because the purpose of the study was to observe the contribution of PEB practice predictor to PEB practice among natural science students. Data of Section A and Section B didn't analyse statistically due to its function to only describe the respondent characteristics and to support the primary data (PEB practice's predictor and PEB practice). Based on the purpose of the study, the hypothesis was:

H0 : the concern of nature condition (C1) didn't correlate with the practice of each form of PEB among natural science students $(\mathrm{C} 2)$

$\mathrm{H} 1$ : the concern of nature condition $(\mathrm{C} 1)$ correlated with the practice of each form of PEB among natural science students (C2)

The closeness level between $\mathrm{C} 1$ and $\mathrm{C} 2$ was expressed in coefficient (r) value and could be interpreted in certain ranges (Table 2). The hypothesis were analysed by significance 
value to verify the hypothesis. If Sig value $>0.05$, this study rejects Ho while Sig value $<$ 0.05 indicated that this study accepts Ho.

Table 2. Interpretation of Coefficient (r) Value [7, modified]

\begin{tabular}{cc}
\hline Range of Coefficient $(\mathbf{r})$ value & Level of Closeness \\
\hline $0.90 \leq \mathrm{r}<1$ or $-0.90 \leq \mathrm{r}<-1$ & Very strong \\
\hline $0.70 \leq \mathrm{r}<0.90$ or $-0.70 \leq \mathrm{r}<-0.90$ & Strong \\
\hline $0.50 \leq \mathrm{r}<0.70$ or $-0.50 \leq \mathrm{r}<-0.70$ & Moderate \\
\hline $0.30 \leq \mathrm{r}<0.5$ or $-0.30 \leq \mathrm{r}<-0.50$ & Weak \\
\hline $0.0 \leq \mathrm{r}<0.30$ or $-0.00 \leq \mathrm{r}<-0.30$ & Very weak \\
\hline
\end{tabular}

\section{Results and Discussion}

\subsection{Section A}

The total of respondents who returned the questionnaire were 37 students. There were 21 students who were in 21-30 years old group (57\%) and had status as master students $(73 \%)$. Based on all respondents responses, there were 20 students who were in $2^{\text {nd }}$ semester $(54 \%)$ when this questionnaire was distributed (Table 3 ).

Table 3. All Respondents Characteristics

\begin{tabular}{lcc}
\hline Respondents Characteristics & Number (n) & Percentage \\
\hline Age Group (years) & 21 & $57 \%$ \\
1. $21-30$ & 12 & $32 \%$ \\
2. $31-40$ & 3 & $8 \%$ \\
3. $41-50$ & 1 & $3 \%$ \\
4. $51-60$ & 27 & $73 \%$ \\
\hline Recent Education Status (when the survey was conducted) \\
\hline 1. Master Programme & 10 & $27 \%$ \\
\hline 2. Doctoral Programme & 6 & $16 \%$ \\
\hline Semester & 20 & $54 \%$ \\
\hline 1. $1^{\text {st }}$ Semester & - & - \\
\hline 2. $2^{\text {nd }}$ Semester & 11 & $30 \%$ \\
\hline 3. $3^{\text {rd }}$ Semester & \multicolumn{2}{l}{} \\
\hline 4. $4^{\text {th }}$ Semester &
\end{tabular}

\subsection{Section B}

All 37 respondents were disagree about the nature as the most important component of environmental science. They opined that environmental science covers the interaction between all living creatures, including human, and non-living ones ecologically, socially, 
and a mixture of both equally. They see environmental science as an inseparable unity of nature, economy, and social science. Most respondents also defined environmental science as a study that teaches how human be able to manage and protect nature without ruining on another living and non-living creature's prosperity and welfare.

All respondents stated that human activities were the main factor of environmental damage. They opined that some human activites such as disposal of undegradable waste to surroundings, natural resources exploitation, land conversion, the excessive use of private transportation, the excessive use of anorganic and chemical materials, and non electricity saving behavior were frequently harm nature's existence in high intensity.

Due to the awareness of those destructive humans activities towards nature, there were 22 respondents opined that nature is in bad condition and there were 8 respondents among them opined that the bad condition of nature didn't capable of sustaining any humans activities while the other 14 respondents opined that nature is still able to support humans activities in spite of its bad condition. However, there were 15 respondents stated the opposite opinion. They opined that nature is in good condition and 13 respondents among them believed that nature is still capable of supporting humans activities and another creatures's welfare. Only 2 respondents among them didn't believe the capability of nature to sustain humans and another living creatures welfare in spite of good condition of nature.

\subsection{Section C}

Electricity saving was the only PEB that performed by all respondents without exception $(0 \%$ of respondents who were never performed it in daily life). In spite of its popularity among respondents, electricity saving was the second popular PEB (the first popular PEB was use of public transportation for long trips) to be performed oftenly by respondents. Use of recycle goods was the last popular PEB to be performed oftenly by respondents. In spite of that finding, respondents were sometimes use some goods with recycle materials. The same occasion also occured with PEB in form of water saving. Respondents did save water and not excessively using it in their daily life, but they did it in some occasions (Table 3).

Table 3. Percentage of PEB Practice Frequency Among Respondents

\begin{tabular}{lcccc}
\hline \multirow{2}{*}{ Items } & \multicolumn{4}{c}{ \% of Respondents } \\
\cline { 2 - 5 } & $1^{*}$ & 2 & 3 & 4 \\
\hline Technical/behavioral change & & & & \\
\hline $\begin{array}{l}\text { Separation of waste types (organic and anorganic } \\
\text { materials) (PEB1) }\end{array}$ & 2.7 & 13.5 & 27 & 56.8 \\
\hline Use of public transportation for long trips (PEB2) & 5.4 & - & 16.2 & 78.4 \\
\hline Use of recycle goods (PEB3) & 8.1 & 24.3 & 43.2 & 24.3 \\
\hline Saving behaviour & - & & & \\
\hline $\begin{array}{l}\text { Turn off the electricity devices when not using it } \\
\text { (PEB4) }\end{array}$ & - & 18.9 & 81.1 \\
\hline Turn off the water tap when not using it (PEB5) & 2.7 & 5.4 & 54.1 & 37.8 \\
\hline Minimalisation of paper materials use (PEB 6) & 8.1 & 18.9 & 32.4 & 40.5 \\
\hline
\end{tabular}

* Likert Scale $(1=$ never, $2=$ rare, $3=$ sometimes, $4=$ often $)$

Overall, most natural science students were already performed PEB in their daily life frequently. This finding was contrary to [8] that indicates the natural science students undertook PEB practice occasionally. Further analysis of this study indicates that most respondents $(n=33)$ were strongly willing to performed PEB due to their concern of nature condition and this was analogous with their status as the students of environmental science 
who studied things related with environment. This finding was supported by the result of correlation analysis indicates that $\mathrm{C} 1$ was correlated with $\mathrm{C} 2$ because the significant value between $\mathrm{C} 1$ and each PEB form was less than 0.05 (rejected H0). However, the concern of nature condition didn't always strongly contribute in all form of PEB practice among respondents because the level of closeness between $\mathrm{C} 1$ and each PEB form was different.

The concern of nature condition was strongly correlated only with use of public transportation for long trips (PEB2) and electricity saving (PEB4) among respondents. The moderate correlation was discovered between the concern of nature condition and water saving (PEB5) while the weak correlation was discovered in PEB1 (separation of wastes based on the organic or anorganic material) and PEB6 (minimalisation of paper materials use). The concern of nature condition had very weak correlation with the respondents action to use some recycle goods for their daily needs (PEB3) (Table 4).

Table 4. Correlation between $\mathrm{C} 1$ and $\mathrm{C} 2$

\begin{tabular}{|c|c|c|c|c|c|c|c|}
\hline \multirow{3}{*}{ Data Analysis } & \multirow{3}{*}{$\begin{array}{l}\text { PEB Practice } \\
\text { Predictor }(\mathrm{C} 1)\end{array}$} & \multicolumn{6}{|c|}{ Forms of PEB (C2) } \\
\hline & & \multicolumn{3}{|c|}{$\begin{array}{c}\text { Technical/behavioral } \\
\text { Change }\end{array}$} & \multicolumn{3}{|c|}{ Saving Behavior } \\
\hline & & 1 & 2 & 3 & 4 & 5 & 6 \\
\hline $\begin{array}{l}\text { Coefficient (r) } \\
\text { Value }\end{array}$ & \multirow{2}{*}{$\begin{array}{l}\text { Respondents } \\
\text { willingness to } \\
\text { behave } \\
\text { environmentally } \\
\text { due to their } \\
\text { concern of } \\
\text { nature condition }\end{array}$} & 0.46 & 0.83 & 0.29 & 0.7 & 0.64 & 0.41 \\
\hline $\begin{array}{l}\text { Sig Value }(\alpha= \\
0.05)\end{array}$ & & 0.22 & 0.06 & 0.43 & 0.23 & 0.06 & 0.15 \\
\hline
\end{tabular}

According to information in Table 3 and Table 4, this study finds that the closeness of $\mathrm{C} 1$ and $\mathrm{C} 2$ was increased as respondents were frequently performed PEB and it also occured conversely. This finding implicitly indicates that the contribution of $\mathrm{C} 1$ to $\mathrm{C} 2$ was indirectly affected by the frequency of PEB practice among respondents. The difference of PEB practice frequency among respondents could be affected by some factors, but monetary saving and habitual were the most influential factors that could predict PEB practice among respondents. In fact, these factors were significantly contribute in any saving behavior, mainly energy saving [9-11]. Unfortunately, due to the purpose of the study, this study didn't analyse the other socio-demographic of respondents that related to incomes and habit for further.

\section{Conclusion}

This study confirms that there is positive correlation between the concern of nature condition and PEB practice among natural science students. However, how often the behavior is carried out by respondents is the determining factor whether or not the PEB occurs. Based on the finding, it was concluded that the environmental concern among respondents doesn't give significant contribution in PEB practice; the frequency of PEB practice does. 


\section{References}

1. S. Liu, L. Guo, Eur. J of Math., Sci., and Tech Edu., 14,7, (2018)

2. A. Chakraborty, M.P. Singh, M.A. Roy, Int. J. of Sust. In High. Edu., 18,7, (2017)

3. A. Zsoka, Z.M. Szerényi, A. Széchy, T. Kocsis, J. of Cle. Prod, 48, (2013)

4. M. Heyl, E.M. Diaz, L. Cifuentes, Rev. Lat. de Psi, 45,3, (2013)

5. L. Fu, Y. Zhang, X. Xiong, Y. Bai, Eur. J of Math., Sci., and Tech Edu. 14,1, (2017).

6. T. Chankrajang, R. Muttarak, R, Ecol. Eco, 131, (2017).

7. Santosa. Hospital statistics: revision edition, Pg. 134, (2018)

8. F. Yildirim, G.A.Y. Işııldar, F. Erkoç, P. Onat, Z.N. Alparslan, J. of Integ. Env. Sci. 12,3, (2015).

9. K.L. Broek, I. Walker, C.A. Klöckner, C. A, En Pol, 132, (2019).

10. H. Lee, K. Kurisu, K. Hanaki, K, Low C. Eco, 4,3, (2013).

11. J. Steinhorst, C.A Klöckner, E. Matthies, J. of Env Psych, 43, (2015). 